Старший научный сотрудник, кандидат юридических наук, доцент

ИГП РАН

\title{
UNDERSTANDING THE LEGAL NATURE OF SMART-CONTRACT
}

Аннотация. Смарт-контракт предназначен для исключения посредничества и сокращения издержек.

Платформа блокчейн необходима для реализации технологии смарт-контрактов. Соответственно, ее обслуживание также требует особой инфраструктуры и правового регулирования.

В статье рассматривается технология смарт-контрактов как изменение концепции контракта как бумаги и переход к контракту как алгоритму.

Таким образом, смарт-контракт можно определить как контракт, который может быть исполнен с использованием специального алгоритма. Как договор, смарт-контракт должен содержать все существенные условия.

Ключевые слова: договор, договорное право, хозяйственное право, смартконтракт, цицрровая экономика, четвертая промыцленная революиия.

Keywords: contract, contract law, business law, smart contract, digital economy, the fourth industrial revolution.

The legal nature of a smart contract is becoming the subject of scientific discussions.

It is proposed to understand a smart contract as an agreement of the parties that exist in the form of a program code functioning in a distributed data registry, which ensures the selfexecution of the terms of such an agreement upon the occurrence of circumstances predetermined in it [1].

A smart contract can become widespread in standard contracts; one of its features can be considered the impossibility of changing it due to the specifics of storing information in distributed registers. In this sense, a smart contract can become a guarantee against a unilateral change in an obligation.

In general, from their possibility of existence in the form of a smart contract, conditions can be conditionally divided into two types: those that can be written in the form of program code, and those that cannot be written in this way, or conditions that can technically be translated into program code, but the parties, for one reason or another, do not want to automate them [2]. Smart 
contracts entered into within a specialized platform pose problems with determining the jurisdiction of the contract. A smart contract (smart contract) can be considered both, possibly, as an offer and acceptance, and as a way of concluding, formalizing relations, as a new type of contract form and as a way of its execution.

The conclusion of contracts in blockchain platforms can lead to the emergence of autonomous legal systems, with their legal regulation and protection of rights, since their execution and contestation will also mainly be carried out within this platform. This especially true for contracts with a foreign element.

A smart contract can also be part of a regular contract. To conclude a smart contract, a special environment is required - a blockchain platform, a distributed data registry, participation in this registry, and identity confirmation.

We believe that a smart contract is both the agreement itself and its new form and execution method, like an algorithm, by analogy with the contract's classical approaches: the contract as a legal relationship, the contract as a document.

A blockchain platform is required to implement smart contract technology. Accordingly, its maintenance also requires special infrastructure and legal regulation.

The smart contract technology is care of the Treaty as the concept paper and the transition to a contract as the concept of the algorithm.

Thus, a smart contract can be defined as a contract that can be entered into, executed, and terminated using a special algorithm. As a contract, a smart contract must contain all essential conditions.

A smart contract can become widespread in standard contracts, one of its features can be considered self-executability and the impossibility of changing it due to the specifics of storing information in distributed registers. In this sense, a smart contract can become a guarantee against a unilateral change in an obligation.

In general, it is noted that from the possibility of their existence in the form of a smart contract, conditions can be conditionally divided into two types: those that can be written in the form of program code and those that cannot be written in this way, or conditions that technically they can be translated into program code, but the parties, for one reason or another, do not want to automate them [2]. Smart contracts entered into within a specialized platform pose problems with determining the jurisdiction of the contract.

A smart contract can be considered both as an offer and an acceptance and as a way of concluding, formalizing relations, as a new type of contract form and its execution.

Smart contract has specific features:

1. Electronic environment of existence 


\section{Self-fulfillment}

3. Immutability, impossibility to change the conditions (how then is the sign of the contract - the possibility of changing legal relations). It can be considered a kind of feature.

\section{Self-defense}

The court considered the first case under Blockchain's contract (A46 -4990 / 2019) [3]. This case study shows that the Blockchain in this solution essentially refers to the exchange of letters by email, confirmed by the screen.

Is this how a transaction should be confirmed on the Blockchain? Where are the traces of the code? Where is the platform itself? There is no clear understanding of what this technology is.

Why did the concept of a smart contract appear, why does this phenomenon attract attention and attempts to explain it and regulate it from a legal point of view?

Anything that is not described by legal concepts and cannot be put into existing legal forms attracts attention. From a legal point of view, the purpose of smart contracts is precisely the occurrence of legal consequences. Therefore they are already legal facts, which means they must be studied, described, and settled. Smart contracts, based on this concept's generalized content, cannot be put into any of the existing legal institutions.

There is no common understanding among specialists of what smart contracts are, due to the lack of a unified legal regulation, the absence of boundaries of the phenomena that describe smart contracts, and various surrogates for the legal regulation of smart contracts.

The first thing that requires legal regulation in smart contracts is the form. The current legislation provides for only two forms for legal facts, the will to aim at the emergence, change, and termination of rights and obligations - this is a simple and written form of a transaction. Concerning each and the forms of transactions, the content of this concept has developed. So the oral form of the transaction is a verbal expression of the form of the transaction since it comes directly from the subject of law, then his will is also expressed in this form. The written form of the transaction is characterized by the consolidation of its content with carriers' help reflecting its content in graphic form. The written form of the transaction must be signed. This is a legal requirement.

The existence of a written form of the transaction is a way to protect the parties' interests to the transaction, fixing the content of the transaction, through which the will of the party to the transaction is reflected. For a smart contract, the way to protect the interests of the parties is expressed in the use of a special platform, a program in which a smart contract is executed, while in this program the distinction between different stages of the existence of a transaction (offer, acceptance, conclusion of a transaction, its execution) is lost. 
There are exceptions to this rule, the use of an electronic digital signature, such surrogates provide the ability to display the electronic version on a tangible medium.

We believe that the March contract cannot be attributed to either the written or the oral form of transactions. Therefore we critically assess the implemented in Art. 160 of the Civil Code ( Federal Law dated 18.03.2019 N 34-FZ "On Amendments to the part of the first, second and third part of the article 1124 of the Civil Code") in the new version of the approach , I suggest conductive applied to smart contractual provisions on written form transactions, unless otherwise specifically stated and does not follow from the essence of the smart contract, only fix the fact that the use of the written form of the transaction is only a surrogate. For the sake of fairness, in these changes, the smart contract is not named.

The reason for the impossibility of applying existing forms of transactions to smart contracts, we believe, is their difference in the method of fixing the content of a smart contract and, therefore, the specifics of proof in case of a form defect.

By the same law, Art. 309 of the Civil Code of the Russian Federation was supplemented with part two of the following content, that is, a conditional smart contract is also a method of execution :

"The terms of the transaction may provide for the fulfillment by its parties of the obligations arising from it upon the occurrence of certain circumstances without the separately expressed additional expression of the will of its parties aimed at fulfilling the obligation by using information technologies determined by the terms of the transaction."

The draft Federal Law N 424632-7 "On Amendments to Parts One, Two and Four of the Civil Code of the Russian Federation" in Art. 309, it was also proposed that the pairing of the fulfilled fulfillment of such obligations is allowed only in cases where the interference of the parties to the transaction or third parties in the execution process is proved" $[4,79-81]$.

A smart contract as a form of contract may remain outside the legal framework for now. Bill N 424632-7 "On Amendments to Parts One, Two and Four of the Civil Code of the Russian Federation" proposed Art. 160 of the Civil Code, add the following paragraph: Unless otherwise provided by law or by agreement of the parties, the written form is also considered to be observed in cases where a person expresses his will using electronic or other similar technical means (for example, by transmitting a signal, including when filling out a form on the network "Internet"), if, according to the conditions of acceptance of such an expression of will, the performance of these actions is sufficient to express the will, or if it follows from the custom that has developed in the relevant field of activity that the performance of these actions is recognized as compliance with the written form of the transaction. 
Another area of application of smart contracts can be considered investing in using digital platforms. Thus, the Federal Law of August 2, 2019, N 259-fz "On attracting investments using investment platforms and on amending certain legislative acts of the Russian Federation," was adopted.

The draft of this law No. 419090-7 "On attracting investments using investment platforms" (after this - the draft law on investment platforms) [5] operated with the concepts of "token" and "smart-contract", with the proviso that these terms are used in this law in the meaning defined in the legislation of the Russian Federation. This directive connects the draft law on investment platforms with another draft law of the developers included in one package of draft laws in which these definitions are given - draft law N 419059-7 on "Digital Financial Assets" (after this the draft law On DFA) [6].

By the Draft Law N 419059-7 "On digital financial assets" [7], a smart contract is an agreement in electronic form, the fulfillment of the rights and obligations under which is carried out by automatic execution of digital transactions in a distributed ledger of digital transactions strictly defined by such an agreement sequence and upon the occurrence of individual circumstances. A digital transaction is understood as an action or sequence of actions aimed at creating, issuing, circulation of digital financial assets.

A digital financial asset is understood to be property in electronic form created using cryptographic means. Digital entries verify the ownership of this property in the digital transaction register. Digital financial assets include cryptocurrency, token. Digital financial assets are not legal tender in the Russian Federation.

If a digital financial asset can be any property in electronic form, why is it called a financial asset? If an asset is equated to property, why is there a new concept? The term "asset" is more of an accounting category than a legal one in Russian law. Thus, the concept of a smart contract by the said draft law is unreasonably narrowed, while a smart contract can be understood as any type of contract regarding various objects, not only digital financial assets [4, 76-82].

The draft law on digital assets under a smart contract means an agreement in electronic form, the fulfillment of the rights and obligations under which is carried out by automatic execution of digital transactions in a distributed ledger of digital transactions in a sequence strictly defined by such an agreement and upon the occurrence of circumstances determined by it.

Further, in the draft law's text on investment platforms, the term "smart contract" is hardly mentioned. However, Art. 9 of this bill is devoted to the specifics of concluding contracts using the investment platform. Agreements between the investment platform participants are concluded using software and hardware for accessing the information contained in the databases of the investment platform. By part 3 of this article, actions aimed at establishing, changing, and 
terminating participants' rights and obligations in the investment platform can be performed using smart contracts.

So, we can state that the draft law's adoption on investment platforms without the draft law On the CFA will make both of these laws unviable since the main definitions used in the first draft are disclosed in the second.

The next element that distinguishes an ordinary contract from a smart contract is expressing and fixing the will.

Will and expression of will is a fundamental institution of civil law. The unity of will and expression of will is a principle of civil law.

The conclusion of the transaction, its execution everywhere, in each element, the parties' will to the transaction is recorded. In the oral form, the offer and emphasis, the transaction's content is a classic form of fixing the will of the parties, since when concluding a transaction orally, the will of the parties to the transaction is recorded in the form. In the written form of the transaction, the parties' will is fixed in the exchange of documents signed by the parties, reading and signing the transaction itself.

One of the principles of civil law is the discreteness of will. The will is independently reflected in each stage of the existence of the transaction. The will is aimed at the emergence of a change or termination of this very fact. In each of the elements, the will has differences in its content. So in the offer, the will is directed precisely at the proposal to conclude a transaction on conditions, while the offeror realizes that the transaction does not yet exist. His will is limited to the proposal to conclude a transaction. In the acceptance, the will is limited by the intention to create a legal relationship, while in the first two cases, the parties tend to legal consequences; the execution also reflects the will of the person, aimed at committing actions reflecting the execution, but the will of the person for the occurrence of legal consequences is indifferent.

In general, the discretion of the person's will in the transaction is entirely consistent with the institution's elements of the transaction. The legislator deliberately breaks the deal into separate stages, since this is how he best protects the parties' interests.

In smart-contracts, such discreteness of will completely loses its meaning, since the protection of the parties' interests is reflected not in the procedure for its implementation, but in the technical ways of protecting the interests of the parties from distorting their will when concluding smart contracts. In a smart contract, the will of the person is all-encompassing. The will to conclude a smart contract reflects all its elements, from the offer to the execution.

The continuation of the discretion of will is the division of the regulation of the transaction into separate elements, which are considered by the legislator as independent, associated with the transaction, but not part of it. So the conclusion of the transaction, expressed 
in the offer and acceptance, is independent institutions, with legal regulation different from the transaction. The main difference is that the transaction generates a legal relationship based on the terms of the parties' transaction.

The most significant difference arises in the legal regulation of the transaction itself. In civil law, a transaction is manifested in several ways: a transaction as a legal fact, a transaction as a legal relationship, a transaction as a document. This is not sensible to a smart contract because it does not include such a mechanism as a deadline.

The conclusion, existence, and execution of a transaction, from civil law, exist only in time, or in its legal expression. Civil law assumes that a person needs a period to conclude a transaction and its execution.

In a smart contract, by expressing a universal will, the time lag of a transaction is practically excluded, a special program concludes and executes a contract, eliminating the will of the parties in its execution. Since the parties do not participate either by their own will or by their actions in the smart contract execution, it makes no sense to talk about the term within the framework of the smart contract.

A smart contract is a holistic phenomenon that includes concluding a deal, the deal itself, and its execution. These elements within the framework of a smart contract do not have their manifestation due to the absence in the smart contract's content, as part of it, of the unity of will regarding the entire smart contract.

By its very nature, a smart contract is not a transaction, since it does not correspond to the transaction model laid down in the Civil Code of the Russian Federation. The smart contract should be regulated as an independent institution of civil law, or the legislator should radically restructure the institution of the transaction to cover the smart contract.

\section{References :}

1. Savelyev A. Legal definition of a Smart contract // [Electronic resource] zakon.ru (date of access 06/15/2020)

2. Yurasov M. Yu., Pozdnyakov D. A. Smart contract and prospects of its legal regulation in the era of blockchain technology. [Electronic resource] https://docs.google.com/document/d/1h7yFK5V1W8OCCAcYWXLIBymgsHjq9BI0QjrY CavvqLU / edit \# (Date of treatment 06/10/2020)

3. Bank of decisions of arbitration courts of the Russian Federation [Electronic resource] http://kad.arbitr.ru/Document/Pdf/b03f81e7-c92b-4f0a-b0fb-4b7d125ef6a3/1a879742-c2ce4dd9-a893-9a5a3158e6d1/A46-4995-2019df_2019es6d1/A46-4995-2019df_2019es isAddStamp = True The (reference date 06/06/2020) 
4. Shapsugova M.D. Implementation of the principles of the digital economy and smart contract technology in the legal regulation of entrepreneurial activity // North Caucasian Legal Bulletin, 2018, N. 2. P. 79-81.

5. Law № 419090-7 On attracting investments using investment platforms. [Electronic resource] URL : https://sozd.duma.gov.ru/bill/419090-7 (date of access 06/18/2020)

6. Law №. 419059-7 On Digital Financial Assets. [Electronic resource] URL : http : // asozd 2. duma . gov . ru / main . nsf /\% 28 Spravka \% 29? OpenAgent \& RN = 419059-7 (date accessed 06/19/2020)

7. Law №. 419059-7 "On digital financial assets" [Electronic resource] http://asozd2c.duma.gov.ru/addwork/scans.nsf/ID/E426461949B66ACC43258256002 17475 / \$ FILE / 419059-7_20032018_419059-7.PDF? OpenElement (date of treatment 06/15/2020). 